\title{
The impact of Board structure on control rights and equitable treatment of stockholder (The case of saudi )
}

\author{
Name : Samy Mahmoud Morad \\ Current job:Assistant Professor of Accounting in Colleges \\ Buraidah civil \\ Email: samy taxation@yahoo.com
}

\begin{abstract}
The primary purpose of corporate governance is to ensure transparency and equality between a corporation and its shareholders. This study examines the impact of board structure on Control Rights And Equitable Treatment Of Stockholder, four board characteristics (board composition, board size, board ownership and CEO duality) have been identified as possibly having an impact on Control Rights And Equitable Treatment Of Stockholder. Findings from the study show that there is strong positive association between board size and corporate financial performance. Evidence also exists that there is a positive association between outside directors sitting on the board and corporate financial performance. However, a negative association was observed between directors' stockholding and firm financial performance measures. In addition, the study reveals a negative association between ROE (measured as the proportion of Profit after tax to issued share capital)and CEO duality, while a strong negative association was observed between ROCE (measured as the proportion of profit after tax to issued share capital plus reserves)and CEO duality. The study suggests that large board size should be encouraged and the composition of outside directors as members of the board should be sustained and improved upon to enhance corporate financial performance.
\end{abstract}


Keywords:Corporate Governance, Board structure, Corporate financial performance, Board size , Board ownership, CEO Duality, Control Rights, Equitable Treatment of Stockholder,Kingdom of Saudi Arabia.

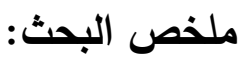

الغرض الرئيسي من حوكمة الشركات هو ضمان تحقيق الثفافية والمساواة بين

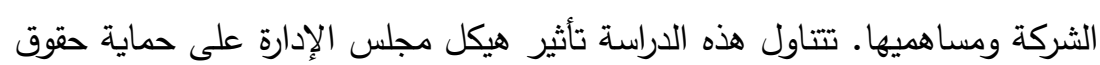

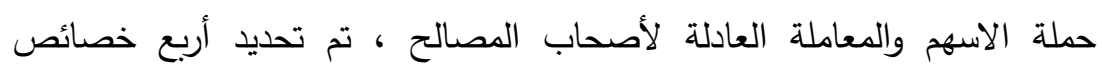

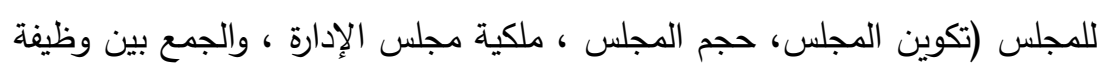

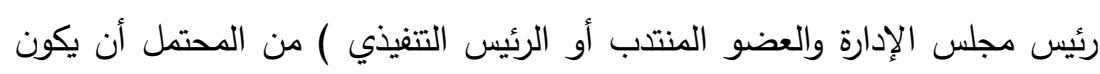

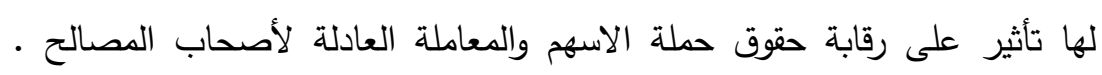

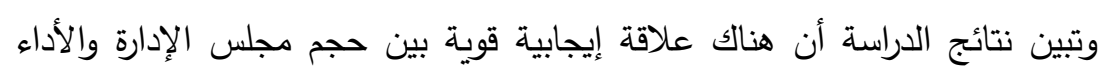

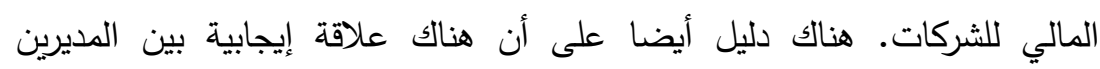

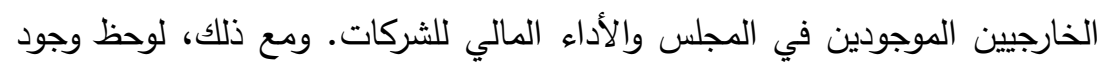
ارتباط سلبي بين المديرين مالكى الأسهم في الشركة وبين قياس الأداء المالى للشركة

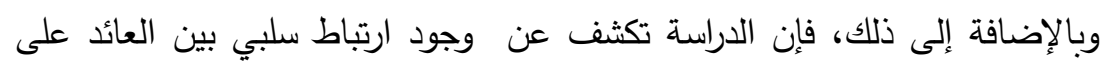
حقوق المساهمين (الذي يمثله العائد على حقوق المساهمين (مقاسا نسبة الربح بعد الإند خصم الضرائب على رأس المال المدفوع) والجمع بين وظيفة رئيس مجلس الإلى الإدارة

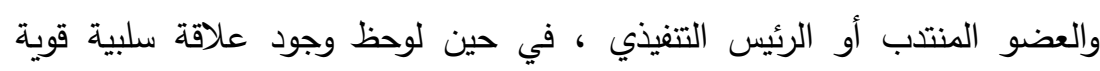

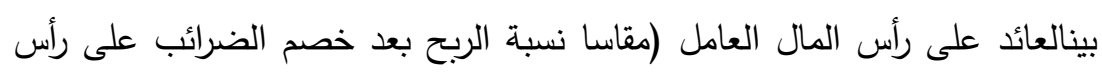

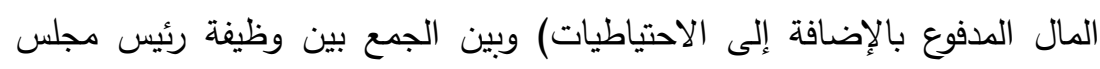

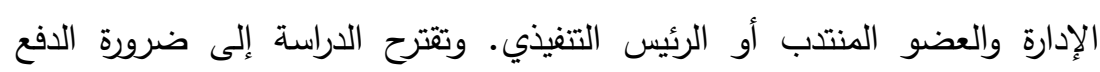




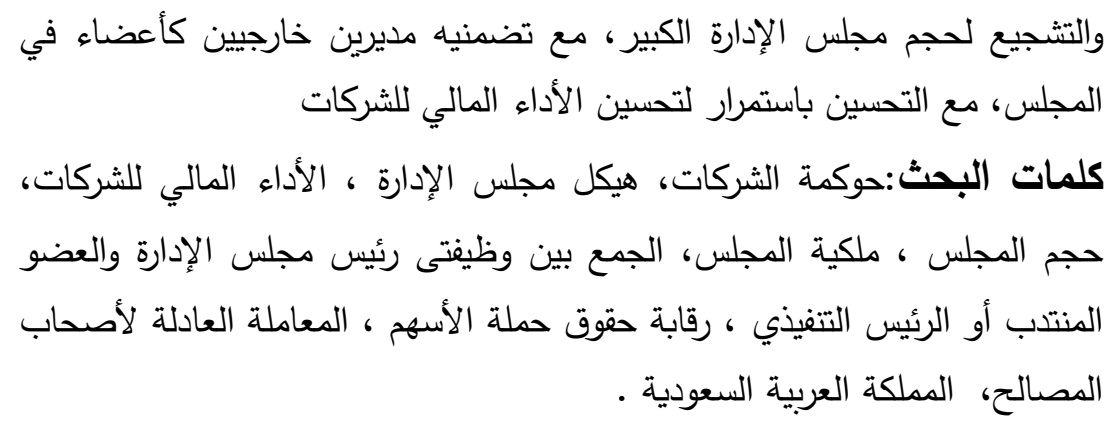

\section{Section I: Research Methodology}

\subsection{Introduction:}

A corporate governance structure combines controls, policies and guidelines that drive the organization toward its objectives while also satisfying stakeholders' needs. A corporate governance structure is often a combination of various mechanisms.( Julie Davoren,Demand Media ,2016) Corporate implosions over the last ten years and the subsequent increased demand for continuous improvement and transparency in the boardroom have heightened the pace of change for boards worldwide

despite the volume of the empirical work, there is no consensus on the impact of corporate governance on firm performance. Consequently, this lack of consensus has produced a variety of ideas (or mechanisms) on how corporate governance influence firm performance. .(Chandrajit Banerjee, Abhay Gupte,2015). In the case of Saudi, poor management and weak internal control systems account for some of the lapses in the operation of some corporate organizations. In addition, technical mismanagement involving inadequate polices, lack of standard practices, poor lending, mismatching of assets and liabilities, weak and ineffective internal control systems as well as poor and lack of strategic planning has bee prevalent in the Saudi corporate industry. Thus, the significance of this study is very high in an environment like Saudi, which is characterized by growing calls 
for effective corporate governance, particularly for public limited liability companies. Thus, we believe that this study should improve our understanding of the relationship between corporate governance and firm performance in Saudi. Especially Control Rights And Equitable Treatment Of Stockholder. This study focuses on the Companies that are quoted on the Saudi Stock Exchange (SSE) to enhance the reliability of information obtained since they are required by law to publish their annual report and accounts. .(AdetunjiBabatunde, OlawoyeOlaniran, 2009) The scope of the study shall cover a period of five years. This is between 2011 and 2015. The choice of the period and the firms included in the analysis were guided by data availability considerations.

\subsection{Statement of the Problem:}

Boards of directors have been largely criticized for the decline in shareholders' wealth and corporate failure. They have been in the spotlight for the fraud cases that had resulted in the failure of major corporations, such as Enron, WorldCom and Global Crossing. In Saudia, a series of widelyl-publicized cases of accounting improprieties have been recorded (for example, Elmagle, Mobilycompany, integrated company, Al Baha). Some of the reasons stated for these corporate failures are the lack of vigilant oversight functions by the board of directors, the board relinquishing control to corporate managers who pursue their own self-interests and the board being remiss in its accountability to stakeholders. As a result, various corporate governance reforms have specifically emphasized on appropriate changes to be made to the board of directors in terms of its composition, structure and ownership configuration (Abidin, Kamal and Jusoff, 2009). Therefore, the study extends and contributes to the body of research using Saudian data to investigate the likely impact of board structure on Control Rights And Equitable Treatment Of Stockholder. The findings would be useful to stakeholders in the 
Saudian Stock Exchange (SSE) as it provides evidence on the relationship between board structure and firm's financial performance.

\subsection{Objectives of the Study}

This study specifically identified the following objective: to evaluate \& examine \& assess and investigate the extent to which board size \& the number of outside directors \& directors' stockholding and CEO duality affects control rights and equitable treatment of stockholder in Saudi.

\subsection{Research Questions}

The study attempts to find answers to the following specific question: to what extent does board size \& the number of outside directors \& directors' stockholding and CEO duality affect control rights and equitable treatment of stockholder? But measurement considerations of the study will be replaced control rights and equitable treatment of stockholder With corporate financial performance.

1.5 Research Hypotheses: The following hypotheses were formulated to guide the researcher in finding answers to the research questions:

H1: There is a negative relationship between Each of( board size\& directors' stockholding\& CEO duality) and corporate financial performance.

H2: There is a positive relationship between proportion of outside directors sitting on the board and corporate financial performance.

The remainder of this paper is organized as follows: Section II discusses The Effects Of Board Structure on Corporate Financial Performance. while Section III captures empirical results and discussion. 


\subsection{Methodology:}

This study uses a survey research design. Since this study is on board structure of quoted companies in Saudia, population of the study is made up of companies listed on the floor of the Saudian Stock Exchange (SSE). However, firms belonging to the financial services industry and regulated utility companies are excluded from the population. This is due to the special regulatory environment in which they operate. A sample consisting of companies listed on the SSE was considered a good representation of quoted companies in Saudia since the ultimate test of a sample design is how well it represents the characteristics of the population it purports to represent (Emory and Cooper, 2003), (Vafeas and Theorodou, 1998; Singh and Davidson, 2003). A sample of thirty (35) quoted companies for the period is between 2011 and 2015. Therefore, respondents cut across public limited companies that were listed on the floor of the SSE. Information relating to firm performance (ROE and ROCE) and board characteristics (board size, board composition, board ownership and CEO duality) was collected from the sampled company's annual reports.

\section{Section II: The Effects Of Board Structure on Corporate Financial Performance}

The application of the principles of corporate governance requirements in Saudi Arabia, According to Article 12,14 of the bylaw of corporate governance. Board size:"the company's system determines the number of board members, not less than three and no more than eleven.", Members non-executives on the board:"must be a majority of the members of the Board of Directors of the non-Member Executives"CEOduality:"prohibits combining the post of chairman of the board and any executive office company, such as the position of Managing Director or 
Chief Executive Officer or General Director" independent members of the board:"must not be less than the number of independent members of the Board of Directors for two, or a third of the members of the Board, whichever is more." , membership of corporate boards Other contributors:"we must Lists membership of the board of directors should not hold more than five joint-stock companies at the same time.

\subsection{Board Composition and Corporate Financial} Performance

Board composition refers to the number of independent nonexecutive directors on the board relative to the total number of directors. An independent non-executive director is defined as an independent director who has no affiliation with the firm except for their directorship (Clifford and Evans, 1997). the board should be comprised of executives and affiliated directors who are advice-oriented. A combined control / advice role is not possible. Executive and affiliated directors cannot monitor executives as they are financially tied to the company, and independent directors cannot advice executives as they do not have an in - depth knowledge of the company. (Leblanc and Gilles, 2005)Tricker noted that board structure distinguishes between those directors who hold management positions in the company and those who do not. Tricker (1994))Zahra and Pearce (1989) identified other dimensions of board structure, such as the number and types of board committees, committee membership, flow of information among these committees and patterns of committee membership.

the results of empirical studies are mixed. A number of studies, from around the world, indicate that non-executive directors have been effective in monitoring managers and protecting the interests of shareholders, resulting in a positive impact on performance, stock returns, credit ratings, auditing, profitability 
etc. (Dehaene et al. ,2001), ( Connelly and Limpaphayom ,2004), (Ashbaugh-Skaife,Collins and Kinney (2006) Rosenstein and Wyatt (1990) find a positive stock price reaction at the announcement of the appointment of an additional outside director, implying that the proportion of outside directors affects shareholders' wealth.Bhojraj and Sengupta ,2003).

In contrast, Dalton et al. s (1995) meta-analysis found that there is no relationship between board structure (leadership and composition) and firm performance. Furthermore, based on a large survey of firms with non-executive directors in the Netherlands, Hooghiemstra and van Manen (2004) conclude that stakeholders are not generally satisfied with the way nonexecutives operate. Haniffa et al (2006) summarize a number of views expressed in the literature which may justify this nonpositive relationship, such as that high proportion of nonexecutive directors may engulf the company in excessive monitoring, be harmful to companies as they may stifle strategic actions, lack real independence, and lack the business knowledge to be truly effective (Baysinger and Butler, 1985; Patton and Baker, 1987; Demb and Neubauer, 1992; Goodstein, Gautum and Boeker, 1994).

2.2 Board Ownership and Corporate Financial Performance

Board Ownership reduces manager-shareholder conflicts in stock ownership by board members (both executive and nonexecutive). To the extent that executive board members own part of the firm, they develop shareholder-like interests and are less likely to engage in behaviour that is detrimental to shareholders. Therefore, managerial ownership is inversely related to agency conflicts between managers and shareholders.(OlayinkaMarte Uadiale,2010)There is no doubt that the structure of ownership of a firm and its internal/external effect has important impact on the capability of the firm to 
respond to external factors impinging on its performance.( AdetunjiBabatunde, OlawoyeOlaniran,( 2009), In contrast to this notion, Demsetz and Lehn (1985) find no link between ownership structure and firm performance, and assert that there is little support for the divergence of interests between managers and shareholders. In empirical contrast to the Demsetz and Lehn (1985) findings, and in line with the beneficial effects of ownership, Morck, Shleifer and Vishny (1988) find that firm performance first rises as ownership increases up to $5 \%$, then falls as ownership increases up to $25 \%$ and then rises slightly at higher ownership levels. They support the theory that managers tend to allocate the firm's resources in their own best interests, which may conflict with those of shareholders.Research on the importance of ownership concentration in the UK has been sparse. Leech and Leahy (1991) find that profitability differences between ownership-controlled (closely-held) firms compared to management-controlled (diffusely-held) firms are only marginal. Such differences are unlikely to be economically meaningful. Moreover, Conyon and Leech (1994) examine, among other things, the mitigating role of ownership concentration in the pay-for-performance relationship. They find a weak relationship between pay and performance, while ownership is found to be insignificant in mitigating this relationship.

\subsection{Board Size and Corporate Financial Performance}

Fama and Jensen (1983) and Donaldson and Davis (1991) argue that different types of directors add value to the company in different ways. This is considered to be a crucial characteristic of the board structure. Large boards could provide the diversity that would help companies to secure critical resources and reduce environmental uncertainties (Pfeffer, 1983; Pearce and 
Zahra, 1992; Goodstein et al., 1994). But, as Yermack (1996) said, coordination, communication and decision-making problems increasingly impede company performance when the number of directors increases. Thus, as an extra member is included in the board, a potential trade-off exists between diversity and coordination. Jensen (1993) appears to support Lipton and Lorsch (1992) who recommend a number of board members between seven and eight. However, board size recommendations tend to be industry-specific.Overall, the empirical evidence indicates that there is no optimal board structure, which goes against the recommendation for independent boards found in codes around the world (Dalton and Dalton, 1993, 1994).Institutional Logics of Corporate Governance and Disclosure on Executive Remuneration It has been argued that it is the board,s role, particularly the roles played by individual directors, that can add value, rather than board structure ( Leblanc and Gilles, 2005; Sundaramurthy and Lewis, 2003 ). Hung (1998) describes six roles for the board: linking to others ( e.g. directors networks ) ; coordinating with stakeholders ; control (e.g. monitoring executives ) ; strategic (e.g. advising executives ); maintenance ( or conformance with societal norms and rules ); and support (e.g. legitimate or rubber stamp executive, decisions).

A review of the empirical evidence on the impact of board size on performance shows mixed results. Dehaene et al. (2001) find that board size is positively related to company performance. However, the results of Haniffa et al. (2006) are inconclusive. Using a market return measure of performance, their results suggest that a large board is seen as less effective in monitoring performance, but when accounting returns are used, large boards seem to provide the firms with the diversity in contacts, experience and expertise needed to enhance performance. 
Yermack (1996) finds an inverse relationship between board size and firm value; in addition, financial ratios related to profitability and operating efficiency also appear to decline as board size grows. Finally, Connelly and Limpaphayom (2004) find that board size does not have any relation with firm performance.

\subsection{CEO-Chairman Duality and Corporate Financial Performance}

Board leadership has only two structures : separate persons as chairman and CEO, or one person as combined chair - CEO . Both structures have pros and cons . Donaldson and Davis ( 1991 ) argue that having an executive chairman will improve the clarity and speed of decision - making because boards will be less likely to oppose or confound executives. On the other hand , Cadbury ( 1992 , p. 21 ) argued against boards having an executive chairman because " ... it represents a considerable concentration of bower. " An executive chairman may subvert the company for their own purposes at the expense of stakeholders . Until recently, executive chairman were common in many countries, particular the US (Daily and Dalton, 1993; Donaldson and Davis, 1991 ). However, having separate persons as chairman and CEO as well as a majority of independent directors is now favoured among policymakers . (Daily and Dalton, 1993; Solomon, 2007 ) .

Under CEO-chairman duality, the CEO of a company plays the dual role of chairman of the board of directors. There are two schools of thought on CEO- chairman duality. Several researchers argue that CEO-chairman duality is detrimental to companies as the same person will be marking his "own examination papers". some researchers believe that since the CEO and chairman are the same person, the company will: (i) 
achieve strong, unambiguous leadership; (ii) achieve internal efficiencies through unity of command; (iii) eliminate potential for conflict between CEO and board chair, and (iv) avoid confusion of having two public spokespersons addressing firm stakeholders (Davis, Schoorman and Donaldson, 1997; Donaldson and Davis, 1991). Consistent with these arguments, Cannella and Lubatkin (1993) report a positive link between a dual leadership structure and financial performance, Brickley, Coles, and Jarrell (1997) find a negative market reaction upon the announcement of splitting roles, and Dedman and Lin (2002) find no evidence of significant abnormal returns upon the announcement of splitting roles in the post-Cadbury period, and Simpson and Gleason (1999) report that companies that combine the roles the CEO and chairman are less likely to be financially distressed. A closer look at the empirical evidence reveals that the relationship between CEO-chairman duality and company performance is mixed and inconclusive. On the other hand, other researchers believe that Separation of duties will lead to: (i) avoidance of CEO entrenchment; (ii) increase of board monitoring effectiveness; (iii) availability of board chairman to advise the CEO, and (iv) establishment of independence between board of directors and corporate management (Baysinger and Hoskisson, 1990; Fama and Jensen, 1983; Rechner and Dalton, 1991).

\section{SectionIII empirical results and discussion}

\subsection{Dependent and Independent Variables}

Dependent variable of the study is Control Rights And Equitable Treatment Of Stockholder, but consideration measurement the Dependent variable of the study is corporate financial performance which is represented by ROE (measured as the proportion of Profit after tax to issued share capital) and ROCE (measured as the proportion of profit after tax to issued 
share capital plus reserves). The independent variables are board size, board composition, board ownership and CEO duality.

\subsection{Statistical Analyses}

For the purpose of empirical analysis, this study uses descriptive statistics, Pearson correlation analysis and linear multiple regression as the underlying statistical tests. The regression analysis is performed on the dependent variable, CORPERF, to test the relationship between the independent variables (board structure characteristics). The regression model utilized to test the relationship between the board characteristics and corporate performance is as follows:

CORPERF $=\beta 0+\beta 1$ BSIZE $+\beta 2$ BCOMP $+\beta 3$ BOSHIP $+\beta 4$ $\mathrm{CEO}+\mathrm{e}$ Where:

$\beta 0=$ Intercept coefficient

$\beta 1=$ Coefficient for each of the independent variables

BSIZE $=$ Number of directors on the board

BCOMP $=$ Proportion of outside directors sitting on the board

BOSHIP = Proportion of total equity owned by executive and non- executive directors respectively.

$\mathrm{CEO}=$ Value zero $(0)$ if the same person occupies the position of the chairman and the chief executive and one (1) for otherwise.

\subsection{Data Analysis and Presentation of Results}

This section of the study is devoted to presenting the results of the analysis performed on the data collected to test the propositions made in the study and answer the research questions. Analyses were carried out with the aid of the Statistical Package for Social Sciences, (SPSS Version 22.0). Table 4.1 shows the descriptive statistics of all the variables used in the study. The mean ROE of the sampled firms is S2 and the mean ROCE is N0.11. The results indicate that for every $\mathrm{S} 100$ invested on equity there is a return of S2. In the same vein, 
return on every S100 of capital employed is N0.11. The average board size of the 35 firms used in this study is 9, while the proportion of the outside directors sitting on the board is $33 \%$. The result also indicates that the proportion of total equity owned by executive and non-executive directors is $40 \%$. The result above also reveals that $100 \%$ of the sampled firms have separate persons occupying the posts of the chief executive and the board chair.

\subsection{Regression Analysis}

A Pearson correlation analysis is performed on the variables to check for the degree of multicollinearity among the variables. The results are shown in Table 4.2, ROE is positively correlated with board size and is significant at (0.008). Similar results appear for board composition though not significant (0.714). However, ROE has a negative relationship with board ownership and CEO duality but not significant. The results also show that a negative and significant (0.001) relationship exists between board composition and board ownership.

Table 4.3, indicates that ROCE is positively correlated with tow of the board structure variables (board size and board composition), A negative correlation is observed between ROCE and board ownership though not significant (0.974). A negative correlation is also observed between ROCE and CEO duality Board ownership also has a negative and significant (0.001) relationship with board composition. A negative correlation is also observed between board ownership and CEO duality.

Tables 4.4a and 5.5a present the model summary. The R2 value, which indicates the explanatory power of the independent variables, is 0.487 and 0.384 respectively. This means that $\% 48$ of the variation in ROE is explained by the variation in the independent variables, while $35.6 \%$ of the variation in ROCE is 
explained by the variation in the independent variables. From the output of the analysis in Tables $4.4 \mathrm{~b}$ and $4.5 \mathrm{~b}$, the analysis of variance (ANOVA) returns significant $p$-values of 0.003 and 0.055 for ROE and ROCE respectively. This shows that the explanatory variables are linearly related to CORPERF and the model seems to have some validity.

Table 4.6 shows the results of the coefficient estimates with ROE as dependent variable. Board size are significant at $p$-value $<0.05$. This indicates a positive relationship with ROE. Board Ownership is significant at $p$-value $<0.10$. Board composition is not significant at either level. Table 4.7 shows the results of the coefficient estimates with ROCE as dependent variable. Three of the board structure variables (board size, board composition and CEO duality) are not significant at $p$-value $<0.05$. Only board ownership is significant at $p$-value $<0.05$. This means that there is a relationship between CEO duality and ROCE.

\subsection{Conclusion}

The aim of this study was to empirically examine the impact of board structure on Control Rights And Equitable Treatment Of Stockholder, consideration measurement the impact of board structure on corporate financial performance in Saudian quoted companies. In achieving this aim, the study obtained data on variables which were believed to have relationship with corporate financial performance and board structure. These variables included ROE, ROCE, BSIZE, BCOMP, BOSHIP, CEO-DUALITY. On the basis of these variables, hypotheses were postulated.

Results from the study indicate that there is strong positive association between board size and corporate financial performance. This is consistent with the findings of Dehaene et al. (2001). to mention a few. A negative association was 
observed between directors' stockholding and corporate financial performance. In addition the study reveals a negative association between ROE and CEO duality, also a strong negative association is observed between ROCE and CEO duality.The study also reveals a positive association between outside directors sitting on the board and corporate financial performance The result is consistent with previous studies (Dehaene et al. 2001, Connelly and Limpaphayom 2004, Rosenstein and Wyatt, 1990) The results imply that large board size performs effectively. There is also evidence that a higher proportion of outside directors on the board have a positive impact on firm financial performance. However, the effect of directors' shareholding on firm performance (measured by ROE) is negative while the relationship between ROCE and directors' shareholding is strongly positive and significant (0.003). Therefore, this study recommends that large board size should be encouraged. The composition of outside directors as members of the board should be sustained and improved upon. Furthermore, this study may be improved upon by including more variables that may affect corporate financial performance. A comparative analysis could be performed between Saudia and other developing countries.

\section{References}

1) Abidin, Z. Z., NurmalaMustaffa Kamal, N. M., \&Jusoff, K. (2009). Board Structure and Corporate Performance in Malaysia. International Journal of Economics and Finance, 1, 150-164 [Online] Available: http://www.ccsenet.org/journal.html. (February 20, 2010)

2) AdetunjiBabatunde, OlawoyeOlaniran,( 2009), The Effects Of Internal And External Mechanism On Governance And Performance Of Corporate Firms In Nigeria, Corporate Ownership \& Control / Volume 7, Issue 2, Continued - 3. 
3) Ashbaugh-Skaife, H., Collins, D., \& Kinney, W. (2006). The Discovery and Consequences of Internal Control Deficiencies Prior to SOX-Mandated Audits. Working paper, University of Wisconsin, University of Iowa, and University of Texas.

4) Baysinger, B., \& Butler, H. (1985). Corporate governance and the board of directors: Performance effects of changes in board composition. Journal of Law, Economics, and Organizations, 1, 101-124.

5) Baysinger, B., \&Hoskisson, R. (1990). The composition of boards of directors and strategic control: Effects on corporate strategy. Academy of Management Review, 15, 1, 72-87.

6) Bhojraj, S., \&Sengupta, P. (2003). Effect of Corporate Governance on Bond Ratings and Yields: The Role of Institutional Investors and Outside Directors. The Journal of Business, 76, 3, 455-475

7) Boyd, B. (1995). CEO duality and firm performance: A contingency model. Strategic Management Journal, 16, 301312 .

8) Brickley, J. A., Coles, J. L., \& Jarrell, G. (1997). Leadership structure: Separating the CEO and Chairman of the Board. Journal of Corporate Finance, 3, 189-220.

9) Cadbury, Adrian,(1992) Report of the Committee on the Financial Aspects of Corporate Governance, Gee, London, p. 15. 
10) Cannella, A. A., \&Lubatkin, M. (1993). Succession as a socio-political process: Internal impediments to outsider selection. Academy of Management Journal, 36, 4, 763-793.

11) Chandrajit Banerjee, AbhayGupte, (2015) Global Trends in Corporate Governance,Deloitte ,confederation of indian industry, For private circulation . Available: https://www2.deloitte.com/content/dam /Deloitte/in/Documents/risk/Corporate\%20Governance

12) Clifford, P., \& Evans, R. (1997). Non- Executive Directors: A Question of independence. Corporate Governance, 5, 4, 224-231.

13) Committee on the Financial Aspects of Corporate Governance (CFACG; Cadbury Committee). (1992). Report of the Committee on the Financial Aspects of Corporate Governance. London: Gee and Co. Ltd Public accounts and Estimates Committee. Fifty second report to Parliament report on the 2002-03 budget estimates.

14) Connelly, J. T., \&Limpaphayom, P. (2004). Environmental reporting and firm performance: evidence from Thailand. The Journal of Corporate Citizenship, 13, 1, 37-149

15) Conyon, M., \& Leech, D. (1994). Top pay, company performance, and corporate governance. Oxford Bulletin of Economics and Statistics, 56, 3, 229-247

16) Daily, C., \& Dalton, D. (1993). Boards of directors leadership and structure: Control and performance implications. Entrepreneurship Theory and Practice, 17(3), 65-81. 
17) Daily, C., \& Dalton, D. (1994). Bankruptcy and corporate governance: The impact of board composition and structure. Academy of Management Journal, 37, 1603-1617.

18) Daily, C., \& Dalton, D. (1995). CEO and director turnover in failing firms: An illusion of change? Strategic Management Journal, 16, 393-400.

19) Dalton, D., \& Daily, C. (1999). What's wrong with having friends on the board. Across The Board, (March), 28-32.

20) Davis, J., Schoorman, F., \& Donaldson, L. (1997). Toward a stewardship theory of management. Academy of Management Review, 22, 1, 20-47.

21) Davis, J., Schoorman, F., \& Donaldson, L. (1997). Toward a stewardship theory of management. Academy of Management Review, 22, 20-47.

22) Dedman, E., \& Lin, S.W. J. (2002). Shareholder wealth effects of CEO departures: Evidence from the UK. Journal of Corporate Finance, 8, 1, 81-104.

23) Dehaene, A., De Vuyst, V. and Ooghe, H. (2001). Corporate Performance and Board Structure in Belgian Companies. Long Range Planning, 34, 3, 383-398

24) Demb, A., \&Neubauer, F. F. (1992): The Corporate Board: Confronting the Paradoxes. Oxford University Press, New York Oxford.

25) Demsetz, H., \& Lehn, K. (1985). The structure of corporate Ownership: Causes and Consequences. Journal of Political Economy, 95, 6, 1155-1175. 
26) Donaldson, L., \& Davis, J. (1991). Agency theory or stewardship theory: CEO governance and shareholder returns. Australian Journal of Management, 16, 1, 49-64.

27) Emory, C.W., and Cooper, D.R. (2003). Business Research Methods, (4th ed.) Illionois: Richard D. Irwin Inc.

28) Fama, E., \& Jensen, M. (1983). Separation of Ownership and Control. Journal of Law and Economics, 26, 301-325.

29) Fama, E., \& Jensen, M. (1983). Separation of ownership and control. Journal of Law \& Economics, 26, 301-325.

30) Goodstein, J., Gautam, K., \&Boeker, W. (1994). The effects of board size and diversity on strategic change. Strategic Management Journal, 15, 241-250.

31) Goodstein, J., Gautum, K., \&Boeker, W. (1994). The effect of Board size and Diversity on Strategic Change. Strategic Management Journal, 15, 3, 241-250.

32) Haniffa, R., \&Hudaib, M. (2006). Corporate Governance Structure and Performance of Malaysian Listed Companies. Journal of Business Finance \& Accounting, 33, 7/8, 10341062. .

33) Hooghiemstra, R., \&Manen, J. (2004) Non-executive Directors in the Netherlands: Another expectations gap? Accounting and Business Research, 34, 25-42.

34) Jensen, M. (1993). The modern industrial revolution, exit, and the failure of internal control systems. The Journal of Finance, 27, 389-410. 
35) Jensen, M.C. (1993). The Modern Industrial Revolution, Exit, and the Failure of Internal Control Systems. Journal of Finance, 48, 3, 831-880.

36) Jill Solomon and ArisSolomon(2007) Corporate Governance and Accountability, Available http://www.untagsmd.ac.id/files/Perpustakaan_Digital.

37) Julie Davoren, Demand Media (2016). Three Types of corporate governance mechanism. http://smallbusiness.chron.com/three-types-corporategovernance-mechanisms-

38) Leblanc and Gilles,( 2005) inside the boardroom: how boards really work and the coming revolution incorporate governance toronto: johnwilly\&sons.

39) Leech, D., \& Leahy, H. (1991). Ownership structure, control type classifications, and the performance of large British companies. Economic Journal, 101, 409, 1418-1437.

40) Lipton, M.,\&. Lorch, J. W. (1992). A Modest Proposal for improved Corporate Governance. The Business Lawyer, 48, 1, 59-77.

41) Morck, R., Shleifer, A., \&Vishny, R. (1988). Management ownership and market Valuation. Journal of Financial Economics, 20, 1/2, 293-315.

42) OlayinkaMarteUadiale ,(2010) The Impact of Board Structure on Corporate Financial Performance in Nigeria, International Journal of Business and Management Vol. 5, No. 10; http://www.ccsenet.org/ijbm.

43) Patton, A., \& Baker, J. C. (1987). Why Won't Directors Rock The Boat? Havard Business Review, 65, 6, 10-18. 
44) Pearce, H., \& Zahra, S. A. (1992). Board Composition from a Strategic Contingency Perspective. Journal of Management Studies, 29, 411- 438.

45) Pfeffer, J. (1983). Organizational demography. In L. L. Cummings, \& B. M. Staw (Eds.), Research in organizational behaviour, 5, 299-357. Greenwich, CT: JAI Press.

46) Pugliese, A., Bezemer, P.-J., Zattoni, A., Huse, M., Van den Bosch, F. A. J., \&Volberda, H. W. (2009). Boards of Directors' Contribution to Strategy: A Literature Review and Research Agenda. Corporate Governance: An International Review, 17(3), 292-306.

47) Rechner, P., \& Dalton, D. (1991). CEO duality and organizational performance: A longitudinal analysis. Strategic Management Journal, 12, 155-160.

48) Rechner, P., \& Dalton, R. (1991). CEO duality and organizational performance: A longitudinal analysis. Strategic Management Journal, 12, 2, 155-160.

49) Rosenstein, S., \& Wyatt, J. (1990). Outside directors, board independence, and shareholder wealth. Journal of Financial Economics, 26, 2, 175-191.

50) Simpson, W.G., \& Gleason, A. E.( 1999), Board structure, ownership, and financial distress in banking firms. International Review of Economics and Finance, 8, 3, 281292.

51) Singh, M., \& Davidson, W. N. (2003). Agency Costs, Ownership Structure and Corporate Governance Mechanism. Journal of Banking \& Finance, 27, 5, 793- 816.

52) SPSS 22 for Windows Evaluation Version 22 (2016). 
53) Sundaramurthy, C., \& Lewis, M., (2003), Control and Collaboration: Paradoxes of Governance. The Academy of Management Review, 28(3), 397-415

54) Tricker, R. (1994). International corporate governance. Singapore: Prentice-Hall.

55) Tricker, R. I. (1994). LEAD Technologies, Inc. International Corporate Governance: Text readings and Cases. Singapore: Prentice-Hall.

56) Vafeas, N. (1999). Board meeting frequency and firm performance. Journal of Financial Economics, 53, 113-142.

57) Vafeas, N., \&Theodorou, E. (1998). The Relationship between Board Structure and Firm Performance in the UK. British Accounting Review, 30, 4, 383-407.

58) Yermack, D. (1996). Higher market valuation of companies with a small board of directors. Journal of Financial Economics, 40, 2, 185-211.

59) Zahra, S., \& Pearce, J. (1989). Boards of directors and corporate financial performance: A review and integrative model, Journal of Management: 15, 291-334.

60) Zahra, S.A., \& Pearce, J. A. (1989). Board of Directors and Corporate Financial Performance: A Review and Integrative Model. Journal of Management, 15, 2, 291-334. 
Table 4.1. Descriptive Statistics

\begin{tabular}{|l|l|l|l|l|l|}
\hline & $\mathrm{N}$ & Minimum & Maximum & Mean & $\begin{array}{l}\text { Std. } \\
\text { Deviation }\end{array}$ \\
\hline ROE & 35 & -.83 & 14.78 & 2.0455 & 3.88182 \\
\hline ROCE & 34 & -2.01 & 1.85 & 0.1134 & 0.59327 \\
\hline BDSIZE & 35 & 4.05 & 15.04 & 8.94 & 2.715 \\
\hline BOSHIP & 35 & 0.00 & 0.91 & 0.5532 & 0.29456 \\
\hline BCOMP & 33 & 0.00 & 1.00 & 0.3911 & 0.39131 \\
\hline CEODUALITY & 35 & 0.00 & 1.00 & 0.88 & 0.352 \\
\hline & 32 & & & & \\
\hline
\end{tabular}

Table 4.2. Results of Correlations - ROE as a financial performance measure $(\mathrm{N}=\mathbf{3 0})$

\begin{tabular}{|c|c|c|c|c|c|c|}
\hline & & $\begin{array}{l}\mathrm{RO} \\
\mathrm{E}\end{array}$ & BDSIZ & $\begin{array}{l}\mathrm{BCOM} \\
\mathrm{P}\end{array}$ & BOSHIP & $\begin{array}{l}\text { CEODUALI } \\
\text { TY }\end{array}$ \\
\hline \multirow[t]{3}{*}{ ROE } & $\begin{array}{l}\text { Pearson } \\
\text { Correlati } \\
\text { on }\end{array}$ & 1 & $\begin{array}{l}0.478(* \\
*)\end{array}$ & 0.081 & -0.232 & -0.263 \\
\hline & $\begin{array}{l}\text { Sig. (2- } \\
\text { tailed) }\end{array}$ & & 0.0086 & 0.714 & 0.374 & 0.433 \\
\hline & $\mathrm{N}$ & & 35 & 35 & 33 & 35 \\
\hline \multirow[t]{3}{*}{ BDSIZE } & $\begin{array}{l}\text { Pearson } \\
\text { Correlati } \\
\text { on }\end{array}$ & & 1 & -.068 & 0.119 & 0.295 \\
\hline & $\begin{array}{l}\text { Sig. (2- } \\
\text { tailed) }\end{array}$ & & & 0.711 & 0.564 & 0.127 \\
\hline & $\mathrm{N}$ & & & 3 & 33 & 35 \\
\hline \multirow[t]{3}{*}{ BCOMP } & $\begin{array}{l}\text { Pearson } \\
\text { Correlati } \\
\text { on }\end{array}$ & & & 1 & *611(* & 0.037 \\
\hline & $\begin{array}{l}\text { Sig. (2- } \\
\text { tailed) }\end{array}$ & & & & 0.001 & 0.866 \\
\hline & $\mathrm{N}$ & & & & 33 & 35 \\
\hline \multirow[t]{3}{*}{ BOSHIP } & $\begin{array}{l}\text { Pearson } \\
\text { Correlati } \\
\text { on }\end{array}$ & & & & 1 & -0295 \\
\hline & $\begin{array}{l}\text { Sig. } \\
\text { tailed) }\end{array}$ & & & & & 0.151 \\
\hline & $\mathrm{N}$ & & & & & 33 \\
\hline $\begin{array}{l}\text { CEODUALI } \\
\text { TY }\end{array}$ & $\begin{array}{l}\text { Pearson } \\
\text { Correlati } \\
\text { on }\end{array}$ & & & & & 1 \\
\hline
\end{tabular}

** Correlation is significant at the 0.01 level (2-tailed). 
Table 4.3. Results of Correlations - ROCE as a financial performance measure. $(\mathrm{N}=30)$

\begin{tabular}{|c|c|c|c|c|c|c|}
\hline & & $\mathrm{ROE}$ & BDSIZE & BCOMP & BOSHIP & CEODUALITY \\
\hline \multirow[t]{3}{*}{ ROE } & $\begin{array}{l}\text { Pearson } \\
\text { Correlation }\end{array}$ & 1 & 0.294 & 0.26 & -.035 & -0.648 \\
\hline & $\begin{array}{l}\text { Sig. } \\
\text { tailed })\end{array}$ & & 0.138 & 0.914 & -0.974 & 0.006 \\
\hline & $\mathrm{N}$ & & 34 & 34 & 32 & 34 \\
\hline \multirow[t]{3}{*}{ BDSIZE } & $\begin{array}{l}\text { Pearson } \\
\text { Correlation } \\
\end{array}$ & & 1 & -0.071 & 0.121 & 0.291 \\
\hline & $\begin{array}{l}\text { Sig. } \\
\text { tailed) }\end{array}$ & & & 0.719 & 0.560 & 0.127 \\
\hline & $\mathrm{N}$ & & & 35 & 33 & 35 \\
\hline \multirow[t]{3}{*}{ BCOMP } & $\begin{array}{l}\text { Pearson } \\
\text { Correlation }\end{array}$ & & & 1 & $\begin{array}{l}. \\
.611(* *)\end{array}$ & 0.041 \\
\hline & $\begin{array}{l}\text { Sig. } \\
\text { tailed })\end{array}$ & & & & 0.001 & 0.912 \\
\hline & $\mathrm{N}$ & & & & 33 & 35 \\
\hline \multirow[t]{3}{*}{ BOSHIP } & $\begin{array}{l}\text { Pearson } \\
\text { Correlation }\end{array}$ & & & & 1 & -.291 \\
\hline & $\begin{array}{ll}\text { Sig. } \\
\text { tailed })\end{array}$ & & & & & 0.142 \\
\hline & $\mathrm{N}$ & & & & & 33 \\
\hline CEODUALITY & $\begin{array}{l}\text { Pearson } \\
\text { Correlation } \\
\end{array}$ & & & & & 1 \\
\hline
\end{tabular}

** Correlation is significant at the 0.01 level (2-tailed).

Table 4.4a. Model Summary

\begin{tabular}{|l|l|l|l|l|}
\hline $\mathrm{R}$ & R Square & $\begin{array}{l}\text { Adjusted R } \\
\text { Square }\end{array}$ & $\begin{array}{l}\text { Std Error } \\
\text { of the } \\
\text { Estimate }\end{array}$ & $\begin{array}{l}\text { Durbin- } \\
\text { Watson }\end{array}$ \\
\hline 0.712 & 0.487 & 0.384 & 3.2154 & 2.654 \\
\hline
\end{tabular}

Dependent Variable: ROE

Table 5.4b. ANOVA

\begin{tabular}{|l|l|l|l|l|l|}
\hline & $\begin{array}{l}\text { Sum of } \\
\text { Squares }\end{array}$ & df & $\begin{array}{l}\text { Mean } \\
\text { Square }\end{array}$ & F & Sig. \\
\hline Regression & 211.784 & 4 & 51.5874 & 5.088 & $0.003^{*}$ \\
\hline Residual & 227.541 & 24 & 9.841 & & \\
\hline Total & 431.657 & 28 & & & \\
\hline
\end{tabular}

Dependent Variable: ROE

* Significant at 0.01 level 
Table 4.5a. Model Summary

\begin{tabular}{|l|l|l|l|l|}
\hline R & R Square & Adjusted R Square & $\begin{array}{l}\text { Std Error of the } \\
\text { Estimate }\end{array}$ & $\begin{array}{l}\text { Durbin- } \\
\text { Watson }\end{array}$ \\
\hline 0.681 & 0.384 & 0.216 & 0.5561 & 1.944 \\
\hline
\end{tabular}

Dependent Variable: ROCE

Table 4.5b. ANOVA

\begin{tabular}{|l|l|l|l|l|l|}
\hline & Sum of Squares & df & Mean Square & F & Sig. \\
\hline Regression & 3.254 & 4 & 0.815 & 2.846 & $0.055^{* *}$ \\
\hline Residual & 6.542 & 23 & 0.291 & & \\
\hline Total & 9.610 & 27 & & & \\
\hline
\end{tabular}

Dependent Variable: ROCE

**Significant at 0.05 level

Table 4.6. Coefficient Estimates

\begin{tabular}{|l|l|l|l|l|l|}
\hline & \multicolumn{2}{|l|}{$\begin{array}{l}\text { Unstandardized } \\
\text { Coefficients }\end{array}$} & $\begin{array}{l}\text { Standardized } \\
\text { Coefficients }\end{array}$ & & \\
\hline & $\mathrm{B}$ & $\begin{array}{l}\text { Std. } \\
\text { Error }\end{array}$ & Beta & $\mathrm{t}$ & Sig. \\
\hline (Constant) & -.700 & 3.415 & & -0.185 & 0.874 \\
\hline BDSIZE & 0.985 & 0.301 & 0.715 & 4.232 & $0.000^{*}$ \\
\hline BCOMP & -.301 & 2.758 & -015 & -.084 & 0.933 \\
\hline BOSHIP & -4.189 & 2.121 & -.411 & -1.988 & $0.070^{* *}$ \\
\hline CEODUALITY & -5.213 & 1.981 & -.471 & -2.851 & $0.013^{*}$ \\
\hline
\end{tabular}

Dependent Variable: ROE

*significant at $0.01 \%$ level

** significant at $0.10 \%$ level 
Table 4.7. Coefficient Estimates

\begin{tabular}{|l|l|l|l|l|l|}
\hline & \multicolumn{2}{|l|}{$\begin{array}{l}\text { Unstandardized } \\
\text { Coefficients }\end{array}$} & $\begin{array}{l}\text { Standardized } \\
\text { Coefficients }\end{array}$ & $\mathrm{t}$ & Sig. \\
& $\mathrm{B}$ & $\begin{array}{l}\text { Std. } \\
\text { Error }\end{array}$ & Beta & $\mathrm{B}$ & $\begin{array}{l}\text { Std. } \\
\text { Error }\end{array}$ \\
\hline (Constant) & -1.211 & 0.594 & & -2.045 & 0.055 \\
\hline BDSIZE & 0.031 & 0.051 & 0.134 & 0.752 & 0.529 \\
\hline BCOMP & 0.285 & 0.491 & 0.128 & 0.588 & 0.594 \\
\hline BOSHIP & 0.850 & 0.377 & 0.199 & 0.867 & 0.514 \\
\hline CEODUALITY & 0.397 & 0.336 & 0.652 & 2.941 & $0.009 *$ \\
\hline
\end{tabular}

Dependent Variable: ROCE

*significant at 0.05 level 


\section{Sample of companies in the study listed financial market} Arabia during the 2011/2015 years.

\begin{tabular}{|c|c|}
\hline The Company's name & Sector \\
\hline 1) Saudi Electricity Company. & Energy \& Utilities \\
\hline 2) The Savola Group Company. & Agriculture and Food Industry \\
\hline 3) Almarai. & Agriculture and Food Industry \\
\hline 4) Qassim Agriculture Company. & Agriculture and Food Industry \\
\hline $\begin{array}{l}\text { 5) Tabuk Agricultural Development } \\
\text { Company. }\end{array}$ & Agriculture and Food Industry \\
\hline 6) Jazan Development Company. & Agriculture and Food Industry \\
\hline 7) STC. & $\begin{array}{l}\text { Communications and Information } \\
\text { Technology }\end{array}$ \\
\hline 8) Etihad Etisalat (Mobily). & $\begin{array}{l}\text { Communications and } \text { Information } \\
\text { Technology }\end{array}$ \\
\hline 9) Saudi Industrial Services. & Multi-Investment \\
\hline $\begin{array}{l}\text { 10) Saudi Pharmaceutical Industries and } \\
\text { Medical supplies }\end{array}$ & Industrial investment \\
\hline $\begin{array}{l}\text { 11-company Saudi Automotive Services and } \\
\text { equipment. }\end{array}$ & Retail \\
\hline $\begin{array}{l}\text { 12-National Company of Agricultural } \\
\text { Marketing. }\end{array}$ & Retail \\
\hline $\begin{array}{l}\text { 13-Ahmed Hassan Fitaihi\& Co. (Fitaihi } \\
\text { Holding Group Company). }\end{array}$ & Retail \\
\hline 14-Jarir Marketing Company. & Retail \\
\hline $\begin{array}{l}\text { 15-ALDREES Petroleum and Transport } \\
\text { Services Company. }\end{array}$ & Retail \\
\hline 16-National Co. for Glass Industries. & Industrial investment \\
\hline $\begin{array}{l}\text { 17-manufacturing packaging materials } \\
\text { company. }\end{array}$ & Industrial investment \\
\hline $\begin{array}{lll}\text { 18-National Company for } & \text { Metal } \\
\text { Manufacturing and Casting. } & & \\
\end{array}$ & Industrial investment \\
\hline 19-Saudi Chemical Company. & Industrial investment \\
\hline 20-Saudi Paper Manufacturing Company. & Industrial investment \\
\hline 21) Arabian Cement Company & Cement \\
\hline 22) TCC. & Cement \\
\hline 23) Qassim Cement Company. & Cement \\
\hline 24) Yamama Cement Company. & Cement \\
\hline 25) Saudi Cement Company. & Cement \\
\hline 26) Southern Province Cement Company. & Cement \\
\hline 27) Yanbu Cement Company. & Cement \\
\hline 28) Eastern Province Cement Company. & Cement \\
\hline 29) Saudi Basic Industries. & Petrochemical Industries \\
\hline 30) National Industrialization Company. & Petrochemical Industries \\
\hline 31) Alujain. & Petrochemical Industries \\
\hline 32) Nama Chemicals Co.. & Petrochemical Industries \\
\hline 33) Saudi Industrial Investment Group. & Petrochemical Industries \\
\hline 34) Sahara Petrochemical Company. & Petrochemical Industries \\
\hline $\begin{array}{l}\text { 35) Saudi International Petrochemical } \\
\text { Company. }\end{array}$ & Petrochemical Industries \\
\hline
\end{tabular}

